\title{
СТАТУС УКРАЇНСЬКОЇ МОВИ \\ В КОНТЕКСТІ БАГАТОМОВНОСТІ: ДЕЯКІ АСПЕКТИ
}

\author{
МАРІЯ РЕДЬКВА \\ Ягеллонський університет, Краків - Польща \\ E-mail: mariya.redkva@uj.edu.pl; ORCID: 0000-0002-1981-8510 \\ JĘZYK UKRAIŃSKI W KONTEKŚCIE WIELOJĘZYCZNOŚCI:
WYBRANE ZAGADNIENIA \\ MARIYA REDKVA \\ Uniwersytet Jagielloński, Kraków — Polska
}

\begin{abstract}
STRESZCZENIE. W artykule przedstawiono sytuację języka ukraińskiego we współczesnych społeczeństwach wielokulturowych. Wybrane zagadnienia prezentują tradycyjny rozwój, przetrwanie oraz zachowanie języka w kraju oraz w warunkach emigracji. Socjolingwistyczne badania tego problemu są bardzo ważne dla tworzenia całościowego obrazu rozwoju języka. Cel artykułu polega na przedstawieniu miejsca języka ukraińskiego w kontekście wielojęzyczności współczesnego świata oraz na porównywaniu takich definicji, jak dwujęzyczność, język ojczysty, język odziedziczony, język docelowy, pierwszy i drugi język w różnych językach (przede wszystkim w angielskim, polskim oraz ukraińskim) w odniesieniu właśnie do języka ukraińskiego. Ważnym aspektem jest porównywanie sytuacji języka ukraińskiego $\mathrm{w}$ diasporze $\mathrm{w}$ różnych krajach oraz znaczenia języka dla przedstawicieli różnych fal emigracji. Znaczenie języka dla każdego kolejnego pokolenia, skutki interferencji językowej, sposoby na zachowanie języka to podstawowe zagadnienia, które są interesujące zarówno dla językoznawców, jak i socjologów.
\end{abstract}

Słowa kluczowe: wielojęzyczność, dwujęzyczność, język ojczysty, język odziedziczony, język docelowy, język ukraiński, migracja 


\title{
UKRAINIAN LANGUAGE IN THE CONTEXT OF MULTILINGUALISM: SELECTED ISSUES
}

\author{
MARIYA REDKVA \\ Jagiellonian University, Cracow — Poland
}

\begin{abstract}
The article deals with the situation of Ukrainian language in contemporary multicultural societies. Selected issues present traditional ways of developing, existence and maintenance of the language in its home country and abroad. Sociolinguistic studies of this problem are very important for the coherent view of language developing processes. The aim of the paper is to represent the place of Ukrainian in the context of multilingualism of the modern world and to compare such definitions as bilingualism, mother tongue, heritage language, target language, first language and second language in different languages (English, Polish and Ukrainian) with reference to Ukrainian. One of the main research issues is comparing of lingual situation of Ukrainian in diaspora in different countries and its meaning for representatives of different waves of emigration. Meaning the language for each next generation, consequences of the language interference, ways of maintenance are the main issues interesting not just for linguists, but for sociologists so far.
\end{abstract}

Key words: multilingualism, bilingualism, mother tongue, heritage language, target language, Ukrainian language, migration

$\mathrm{M}$ овознавці неодноразово аналізували явище українсько-російської двомовності, яке простежуємо в мовному просторі України. Однак співіснування української мови з іншими мовами має тривалу історію та на сьогодні широкі дослідницькі перспективи. 3 огляду на активні міграційні процеси, існування українських громад у світі доцільно розмірковувати про функціювання української мови в багатомовному середовищі, адже проживання українців в іншомовному середовищі, безперечно, змушує до опанування на певному рівні та вживання нової (чужої) мови й водночас змінює межі та сфери використання рідної мови. 3 урахуванням викладеного вище постає питання про встановлення статусу рідної мови в сучасному мультикультурному та полілінгвальному світі за умов розширення кордонів iі функціювання, а вибір мови спілкування залежить від можливості обрати місце проживання й підкреслити свою ідентичність. Французький філософ Б. Кассен зауважує: „Рідна мова — це мова, у якій ми народилися, чи ті мови, у яких ми народилися, і вона не є єдиною можливою. [...] Рідна мова — це мова, якою ми просякнуті, ми «купаємося» в іï звучанні й можемо гратися словами, чути відлуння значень, вигадувати нові слова: ми - господарі цієї мови, й, однак, це вона тримає нас у своїх руках. Це надзвичайні стосунки. Ми iï господарі, бо можемо нею висловити все, що хочемо, але все ж таки вона 
тримає нас у руках, бо це вона визначає наш спосіб мислення, наш спосіб життя, наш спосіб буття” [Кассен 2016: 11-12]. В. Русанівський визначає рідну мову як „мову, з якою людина входить у світ, прилучається до загальнолюдських цінностей у їх нац. [національній] своєрідності. Людина стає свідомою, оволодіваючи мовою своїх батьків. [...] Р. м. [Рідна мова] сприймається не просто як засіб комунікації, не тільки як знаряддя формування думок, а значно інтимніше - як одне з гол. [головних] джерел патріот. [патріотичних] почуттів, як рецептор духовно-емоц. [емоційної] сфери людини. [...] Р. м. [Рідна мова] єднає, консолідує народ у часі і просторі” (доповнення в квадратних дужках автор. - М. Р.) [Українська мова: Енциклопедія 2004: 553]. Польська дослідниця Е. Ліпінська сформулювала визначення рідної мови на основі аналізу дефініцій, запропонованих мовознавцями світу, напр.: „Рідна мова це перша мова, яку людина пізнає і засвоює, якої торкається і за допомогою якої налагоджує зв’язок з довкіллям. Вона має велике значення для пізнання світу людиною, формування іiі як особистості. Зазначене й мотивує те, що людина ототожнює рідну мову зі своїм єством, а в дорослому житті зазвичай використовує їі для того, щоб мислити нею, бачити сновидіння, рахувати та молитися" [Lipińska 2003: 15] (переклад автор. — М. Р.).

Ідентифікування себе з певною мовою - це природно, однак у сучасному світі неможливо існувати герметично в межах однієї мови, навіть проживаючи у своїй країні. Б. Кассен розмірковує про володіння кількома мовами: „Що це, власне, означає: знати багато мов? Можливо, це мати багато тятив до свого лука. Багато мов - це багато світів, багато способів відкритися світові” [Кассен 2016: 16-17]. Багатомовність зумовлюють геополітичні чинники, міграційні та освітні зміни. Водночас вони розширюють межі використання мов на певному рівні поза кордонами країни, змінюють їхні функції та впливають на формування варіантів мов на різних територіях. Мовна інтерференція, запозичення, витворення Franca Lingua чи Global English це все наслідки співіснування й взаємних контактів мов, що зумовлене викликами цивілізації. У сучасній соціолінгвістиці найчастіше статус української мови визначають як складник російсько-української двомовності через урахування історичної та політичної ситуацій. Однак це лише один 3 варіантів функціювання української мови на мовній карті світу. Українсько-російські контакти радянського періоду однозначно можна окреслити як диглосію із чітко окресленою тенденцією не лише до так званого зближення двох мов, але й функційного обмеження в суспільстві. Проблема українсько-російської диглосії та білінгвізму висвітлена в дослідженнях В. Бріцина [Українська мова: Енциклопедія 2004: 131-132], В. Лизанчука [Лизанчук 2008], Я. Радевича-Винницького [РадевичВинницький 2011], С. Узунова [Узунов 2014] та ін. Наслідки впливу тривалої мовної політики радянської доби до сьогодні прочитуються в українських реаліях. Л. Масенко в праці Мова радянського 
зму детально й різнобічно аналізує мовні впливи та витворення нових форм у радянський період. Мовну ситуацію в пострадянській Україні вона окреслює як “розкол на мовному грунті” й „це не тільки опозиція двох мов, це протистояння ідентичностей і цивілізаційних орієнтацій населення" [Масенко 2017: 219]. Упродовж майже трьох десятиріч незалежності України, з одного боку, це явище все ще панує в мовному просторі зі зміцненням окремих маркерів (послуговування державною мовою здебільшого в діловодстві, книгодрукуванні, художній літературі та сфері освіти), з другого боку, медіапростір створив концепцію ілюзорної двомовної ситуації, чим надалі пропагує й підтримує функціювання російської мови на всіх рівнях.

На сьогодні, на жаль, активно не обговорюється мультикультурність й багатомовність, що мали місце в українських містах у довоєнний період, як не пишуть і про двомовність пограниччя, українсько-польську, українсько-німецьку двомовність 3 огляду на колишній територіальний розподіл сучасної України між різними імперіями. "Поза кадром" залишаються позиції двомовних письменників XIX - поч. XX ст., для яких вибір мови ставав вибором ідентичності. Однією з грунтовних праць, у якій розкрито аспект розвитку, функціювання та співіснування української мови з іншими мовами на поч. ХХ ст., є дослідження Ю. Шевельова Українська мова в першій половині двадиятого століття (1900-1941): Стан і статус [Шевельов 2009].

У сучасній Україні двомовність також не одновимірна з огляду на зростання кількості “мішаних" родин, міграцію сімей, досвід проживання дітей з раннього віку за кордоном, що спричиняє збільшення кількості дітей-білінгвів тощо. Питання двомовності в еміграції не однозначне й отримує різні погляди 3 кожною наступною хвилею й типом еміграції. Так, перші хвилі еміграції до Південної Америки, Сполучених Штатів Америки, Канади, Австралії, зокрема еміграція к. XIX - поч. XX ст. охопила передусім малоосвічені прошарки населення. Умови проживання в спільнотах емігрантів, доступність освіти, сфера діяльності не сприяли асимілюванню першого покоління мігрантів ні на соціальному, ні на мовному рівнях. Двомовність наступного покоління можна схарактеризувати як володіння одним $з$ діалектних варіантів української мови, здебільшого говорів, поширених на Східній та Західній Галичині, Буковині, оскільки найбільше емігрантів було саме із цих земель, та набутої вже в середовищі іноземної мови.

У польському мовознавстві двомовність саме перших емігрантів у Бразилії детально описав професор В. Мьодунка [Miodunka 1997]. Крім того, цей учений здійснив загальний огляд стану досліджень Полонії у світі [Miodunka 1999].

Американська дослідниця К. Сілз на основі порівняння досліджень різних часових періодів коротко описує мовну ситуацію різних поколінь українських емігрантів у США: „Більшість представників української діаспори в США 
можна зарахувати до категорії носіїв галицького варіанта української мови. Спільнота американців українського походження грунтується на еміграції початку двадцятого сторіччя, коли виникла на заході України та сході Польщі своєрідна галицька нація. Сучасній українській мові притаманний більшою мірою вплив російської мови, відповідно, на українській мові, якою говорять у США, позначилися галицька говірка, польська та англійська мови, а насамперед англійська. 3 огляду на значні та помітні відмінності між сучасною українською мовою й галицькою говіркою, засіб спілкування представників української діаспори часто називають «українською куховарок», що мало би характеризувати її нестандартність" [Seals 2014] (переклад автор. - М. Р.). На сучасному етапі нащадки перших емігрантів якщо й володіють мовою батьків, то володіють нею як успадкованою. Це передбачає обмеження можливостей використання мови - у родинному колі, церковній спільноті й недільній школі. Соціолінгвістичні дослідження інших мов засвідчують, що спілкування в родині із часом також відбувається з використанням не лише однієї мови, зокрема покоління братів-сестер часто надає перевагу мові середовища.

На жаль, ці явища недостатньо описані в науковій лінгвістичній українській літературі, але з огляду на однакові умови емігрування частково можемо порівняти мовну ситуацію, у якій опиняються польські та українські емігранти, на основі досліджень польських мовознавців.

Загалом у літературі використовують опозиції 'рідна мова' ('mother tongue') — 'іноземна мова' ('foreign language'), 'перша мова' ('first language' L1 - 'друга мова' ('second language' — L2), 'вихідна мова' ('source language') — 'target language' (опрацювання цього терміна в українському мовознавстві ще не здійснене, оскільки не знайдено точного відповідника в спеціальній літературі). Більшість учених дотримується думки, що не слід ототожнювати поняття “іноземна мова" та “друга мова”. Услід за Д. Кристалом, Е. Ліпінська вважає, що друга мова засвоюється без участі вчителя й без формальних інструкцій, у природному середовищі, де послуговуються цією мовою. Натомість іноземну мову вивчають у штучних умовах, найчастіше в школі, на курсах тощо. Зміст понять “іноземна мова” та “друга мова” часто збігаються з “target language”, однак останнє має ширше значення й охоплює два попередні [Lipińska 2003: 42-43]. В українській лінгводидактиці вперше описано українську мову як іноземну мову, другу мову, успадковану мову, “украӥнську куховарок”, домашню мову та зіставлено запропоновані терміни з поняттями в інших мовах у дослідженні О. Туркевич [Туркевич 2015: 17-19]. Процеси засвоєння дорослими та дітьми мови нового середовища відбуваються по-різному. Р. Елліс обгрунтовує вживання термінів second language acquisition та second language learning щодо вивчення другої мови [Ellis 1994]. Для дорослих це передусім так звана 'target language', тобто мова для комфортного функціювання в нових умовах. Діти засвоюють другу мову при- 
родно легко, оскільки для них вона стає функційно першою мовою - мовою освіти, спілкування з ровесниками та оточенням загалом. На цьому етапі звужується використання рідної мови та обмежується її функціювання поза домом і родиною. Це закономірний процес, що відбувається незалежно від країни та ії титульної чи державної мови. Механізми адаптування до нового мовного середовища відбуваються аналогічно.

Нова еміграційна хвиля, що почалася в 90-х рр. ХХ ст., умовно кажучи, привезла із собою на американський континент, в Австралію та Канаду сучасну українську літературну мову, що сприяло активізуванню нового етапу розвитку українськомовного середовища в цих країнах. Помітні зміни в ставленні до мови серед мігрантів: $з$ одного боку, розвивають системи недільних шкіл і товариств для дітей, створюють сучасні підручники для вивчення української мови; з другого - помітною є тенденція до асимілювання, відповідно, питанню мовного виховання не надають належної уваги. Значення рідної другої - іноземної - мови поступово змінюється. Трудова міграція до Англії, Італії, Іспанії та Португалії, що згодом перетворилася на досить численну еміграцію, може стати прикладом дослідження адаптації сучасних емігрантів у нових країнах без міграційної передісторії та виникнення нових видів двомовності чи й багатомовності.

Певну зміну масштабів білінгвізму спостерігаємо в контексті українсько-польської двомовності. Це приклад двомовності етнічних груп, які з огляду на історичні обставини та перерозподіл кордонів опинилися в іншій державі. На Галичині протягом 1886-1939 рр. діяли так звані утраквістичні школи, у яких частину навчальних дисциплін викладали однією мовою, а частину - іншою. Польська мова як мова освіти та мова офіційного спілкування набувала вагомого значення для двомовних користувачів, однак першість української зберігалася. Після Другої світової війни та остаточно після акції "Вісла" 1947 р. українська мова перестала бути мовою освіти національних меншин на території Польщі. Отже, українська мова стала винятково мовою домашньою чи так званою “українською куховарок”. Це зменшило її можливості щодо закономірного розвитку відповідно до потреб суспільства та зумовило звуження її функцій до місцевого діалектного варіанта. Незважаючи на суспільні зміни всередині 50-х рр. XX ст., відновлення кількох українських шкіл на півночі країни, відродження україністики у Варшавському університеті, що оприсутнювало українську меншину та мову в офіційному просторі, українсько-польський білінгвізм у варіанті домашньої мови проіснував до сьогодні. Наслідком такої ситуації та неминучої мовної інтерференції стало активне запозичення та адаптування полонізмів, зокрема на позначення нових предметів та явищ, назв яких не існувало в говірках.

Нові міграційні процеси між Україною та Польщею, що активізувалися після революції 2013-2014 рр. та початку українсько-російської війни, унесли 
зміни і в суспільну, і в мовну картину світу сучасної Польщі. Про двомовність серед трудової міграції недоцільно говорити, оскільки опанування мови на певному рівні мотивоване передусім умовами роботи. Натомість студентська молодь та діти, які або приїжджають у ранньому віці, або народжуються Польщі, безумовно, стають двомовними. Польська мова - це і для першої групи, і для другої насамперед мова освіти, а з віком стає мовою ширшого середовища. Функціювання української мови звужується до домашнього спілкування та кола знайомих, а також залишається засобом комунікації з родичами з України.

3 мовного погляду еміграція к. XX - поч. XXI ст. порівняно 3 попередніми найбільш різноманітна, оскільки серед емігрантів багато російськомовних осіб та людей, які послуговуються суржиком. Це один із чинників, що не сприяє консолідації, єднанню спільноти з метою збереження своєї ідентичності за кордоном. Відкриваються українські недільні дитячі садочки й класи в школах; усе більше шкіл запрошують до співпраці культурних консультантів, які сприяють адаптуванню та кращій співпраці вчителів 3 дітьми з України; консульства та релігійні громади працюють над залученням українських родин до спільних проектів. Водночас серед українців спостерігаємо тенденцію до максимального асимілювання. Це виявляється в різних аспектах — від зміни документального ідентифікування імені, відтворення його польською мовою до вживання польської мови під час спілкування в родині, навіть у “незмішаних” сім'ях. Спілкування батьків 3 дітьми польською в домашніх умовах стало доволі поширеним явищем. Зокрема, діти часто втрачають основні навички активного спілкування, навіть якщо рідною й першою мовою в них була українська. Серед студентської молоді, для якої польська стає другою й функційно важливою мовою для навчання, роботи й проживання в польськомовному середовищі, спостерігаємо тенденцію до вживання не лише української та польської мов, а й російської, хоча російська не є їхньою рідною, другою чи домашньою мовою. Тому в цьому середовищі формується тримовна картина на рівні неформального спілкування та спілкування в соціальних мережах. Примітним аспектом існування у двох і більше мовах є спілкування в інтернет-просторі (ця тема потребує окремого аналізу з огляду на розмаїтість явищ та процесів у творенні подібного дискурсу). Спостерігаємо аналогічне, як у США, мовне розмежування локальної національної меншини та нових емігрантів, що стає причиною створення окремих осередків спільноти. Зазначена ситуація ще в розвитку, і про їі наслідки та причини можна буде зробити висновки лише через кілька років.

Отже, пропоноване дослідження — це лише спроба моделювання загальної картини мовних проблем, що стосуються функціювання української мови в різних країнах в умовах багатомовності сучасного світу. Українсько-англійська, українсько-італійська, українсько-іспанська, українсько-португальська, 
українсько-польська, українсько-чеська двомовність та інші - це ті форми існування української мови за кордоном, які можна сьогодні спостерігати. Проблеми білінгвізму потребують детального соціолінгвістичного дослідження. Побіжний розгляд процесів розвитку та збереження української мови в умовах еміграції засвідчив, по-перше, закономірність процесів, що відбуваються з кожною мовою, “вивезеною” за межі рідної країни, а по-друге, унікальність цього процесу, коли діаспора зберігає українську мову довоєнного періоду, діалектні варіанти й водночас сучасну українську мову з її новими явищами, запозиченнями, суржиковими елементами. Незважаючи на деякі закономірності адаптування носіїв певної мови в чужомовному середовищі, кожне середовище та кожна мова мають свої особливості.

Перспективою дослідження актуалізованої в цій статті проблеми вважаємо відстеження інтерференції рідної мови та мови середовища, способів збереження та розвитку рідної мови, передавання ії наступним поколінням на прикладі різних мов в умовах активних міграційних процесів в Україні протягом останніх десятиліть.

\section{Список використаної літератури}

Кассен Б., Більше однієї мови, Київ: Дух і літера, 2016.

Лизанчук В., Геноцид. Етноцид. Лінгвоциид украйнської нації, Львів: Вид. центр ЛНУ ім. Івана Франка, 2008.

Масенко Л., Мова радянського тоталітаризму, Київ: Кліо, 2017.

Радевич-Винницький Я., Двомовність в Украӥні: теорія, історія, мововживання, КиївДрогобич: Посвіт, 2011.

Туркевич О., Становлення терміносистеми методики викладання украӥнської мови як іноземної, Львів: Вид. центр ЛНУ ім. Івана Франка, 2015.

Узунов С., Мовна ситуація в Україні: білінгвізм чи диглосія?, [в:] „Українське мовознавство”, 2014, № 1 (44), с. 81-93.

Українська мова: Енциклопедія, Київ: Українська енциклопедія, 2004.

Шевельов Ю., Українська мова в першій половині двадиятого століття, [в:] Вибр. праиі, кн. I. Мовознавство, упор. Л. Масенко, Київ: Вид. дім „Києво-Могилянська Академія”, 2009, c. 26-279.

Ellis R., The study of Second Language Acquisition, Oxford University Press, 1994.

Lipińska E., Język ojczysty, język obcy, język drugi. Wstęp do badań dwujęzyczności, Kraków: Wyd-wo Un-tu Jagiellońskiego, 2003.

Miodunka W., Badania bilingwizmu i języka Polonii Brazylijskiej na tle badań języka polskiego w świecie, [w:] „Przegląd Polonijny”, 1997, zesz. 4, s. 5-18.

Miodunka W., Stan badań nad Polonia i Polakami w świecie, [w:] „Przegląd Polonijny”, 1999, zesz. 1, s. 87-104 . 
Seals C., Heritage Voices: Language — Ukrainian, [in:] Електронний ресурс: https:// www.researchgate.net/publication/273444280_Heritage_Voices_Language_Ukrainian (01.03.2019).

\section{Spysok vykorystanoi literatury [References]}

Kassin B., Bilshe odniiei movy [More Than One Language], Kyiv: Duh i litera, 2016. Lyzanchuk V., Henotsyd. Etnotsyd. Linhvotsyd ukrainskoi natsii [Genocide, Ethnocide, Linguicide of the Ukrainian Nation], Lviv: Vyd. tsentr LNU im. Ivana Franka, 2008.

Masenko L., Mova radianskoho totalitaryzmu [The Language of Soviet Totalitarianism], Kyiv: Klio, 2017.

Radevych-Vynnytskyi Y., Dvomovnist v Ukraini: teoriia, istoriia, movovzhyvannia [Bilingualism in Ukraine: Theory, History, Language Use], Kyiv-Drohobych: Posvit, 2011.

Turkevych O., Stanovlennia terminosystemy metodyky vykladannia ukrainskoi movy jak inozemnoi [Main Tendencies of the Terminology Formation of the Methodology of Teaching Ukrainian as a Foreign Language], Lviv: Vyd. tsentr LNU im. Ivana Franka, 2015.

Uzunov S., Movna sytuatsiia v Ukraini: bilinhvizm chy dyhlosiia? [Language Situation in Ukraine: Bilingualism or Diglosia?], [v:] „Ukrainske movoznavstvo”, 2014, № 1 (44), s. 81-93.

Ukrainska mova. Entsyklopediia [Ukrainian Language: Encyclopedia], Kyiv: Ukrainska entsyklopediia, 2004.

Shevelov Yu., Ukrainska mova v pershii polovyni XX stolittia (1900-1941): Stan i status [The Ukrainian Language in the First Part of the XXth Century], [v:] Vybr. pratsi, kn. I: Movoznavstvo, upor. L. Masenko, Kyiv: Vyd. dim “Kyjevo-Mohulanska Akademia”, 2009, s. 26-279.

Ellis R., The study of Second Language Acquisition, Oxford University Press 1994.

Lipinska E., Język ojczysty, język obcy, język drugi. Wstęp do badań dwujęzyczności, Kraków: Wyd-wo Uniwersytetu Jagiellońskiego, 2003.

Miodunka W., Badania bilingwizmu i języka Polonii Brazylijskiej na tle badań języka polskiego w świecie, [w:] „Przegląd Polonijny”, 1997, zesz. 4, s. 5-18.

Miodunka W., Stan badań nad Polonia i Polakami w świecie, [w:] „Przegląd Polonijny”, 1999, zesz. 1, s. 87-104.

Seals C., Heritage Voices: Language — Ukrainian, [in:] Elektronnyi resurs: https://www. researchgate.net/publication/273444280_Heritage_Voices_Language_Ukrainian (01.03.2019). 